\title{
Analisis Progres Pencapaian Millenium Development Goals Provinsi Jawa Timur (Progress Analysis Of Achievement Millenium Development Goals In The Province Of East Java)
}

\section{Roziana Ainul Hidayati}

Program Studi Manajemen, Fakultas Ekonomi Dan Bisnis

Universitas Muhammadiyah Gresik, Jawa Timur, Indonesia

roziana.umg@gmail.com

\begin{abstract}
Abstarct
The problem of reducing poverty is not an easy problem. Poverty alleviation programs must be on target, the right activities, the right program, the right location and the right budget. Many program activities to reduce poverty that are only imitating the previous year's program without first reviewing the problem and also often the programs that are run modeled on other regional programs that cause poverty can be different. This reseach purpose to identify the progress in achieving the targets of the " $1 C^{\prime \prime}$ goals which are still slow and to identify areas in East Java that are still experiencing poverty severity with based on the indicator of target MDGs. And the method used for this purpose is with using the measurement of the PHI Index and the Chart Priority MDGs. The results show the achievement of the progress of the MDGs in East Java from 7 (seven) progress of the existing Goals "IC Target" exception "fast" in Matlamat I. To the IC progress target in achieving East Java Province "slow". The regions experiencing poverty embrace for Goal I are Sampang and Pamekasan. , Regions that experience poverty embrace for Target III are Bangkalan and Pamekasan. Areas that experience poverty embrace for Objective IV are Probolinggo and Bangkalan. Areas that experience poverty embrace for Goal V are Bangkalan and Sumenep. The regions experiencing poverty embrace for Goal and VII are Sampang Regency. The area that has the highest poverty rate for each MDG Matlamat is Bangkalan in Goals III, IV and V..
\end{abstract}

Keywords: Poverty, MDGs, Poverty and Hunger Index, progress

\begin{abstract}
Abstrak
Masalah pengurangan kemiskinan bukanlah masalah yang mudah. Program pengentasan kemiskinan harus tepat sasaran, dengan kegiatan yang tepat, program yang tepat, lokasi yang tepat, dan anggaran yang tepat. Banyak program kegiatan pengurangan kemiskinan yang hanya meniru program tahun sebelumnya tanpa terlebih dahulu meninjau masalah dan seringnya program yang dijalankan dimodelkan pada program regional lainnya yang menyebabkan kemiskinan menjadi berbeda. Penelitian ini bertujuan untuk mengidentifikasi kemajuan dalam mencapai target "IC" banyak tujuan yang masih lambat dan untuk mengidentifikasi daerahdaerah di Jawa Timur yang masih mengalami kemiskinan yang parah dengan berdasarkan indikator target MDGs. Metode yang digunakan untuk tujuan ini adalah dengan menggunakan pengukuran Indeks PHI dan MDGs Prioritas Grafik. Hasil penelitian menunjukkan pencapaian kemajuan MDGs di Jawa Timur dari 7 (tujuh) kemajuan Sasaran "IC Target" yang ada, kecuali "cepat" di Matlamat I. Untuk target kemajuan IC dalam mencapai Provinsi Jawa Timur "lambat". Daerah
\end{abstract}


yang mengalami pelukan kemiskinan untuk Sasaran I adalah Sampang dan Pamekasan. Wilayah yang mengalami kemiskinan untuk Sasaran III meliputi Bangkalan dan Pamekasan. Wilayah yang mengalami kemiskinan untuk Tujuan IV adalah meliputi Probolinggo dan Bangkalan. Wilayah yang mengalami kemiskinan untuk Sasaran V adalah meliputi Bangkalan dan Sumenep. Daerah yang mengalami kemiskinan untuk Sasaran dan VII adalah Kabupaten Sampang. Daerah yang memiliki tingkat kemiskinan tertinggi untuk setiap MDG Matlamat adalah Bangkalan dalam Tujuan III, IV dan V ..

Kata kunci: Kemiskinan, MDGs, Indeks Kelaparan, kemajuan

\section{PENDAHULUAN}

Pengentasan Kemiskinan merupakan masalah yang sangat kompleks dan mempunyai dimensi tantangan lokal, nasional, regional maupun global. Upaya mengatasi masalah kemiskinan karenanya tak bisa dilepaskan dari strategi nasional untuk mewujudkan pembangunan berkelanjutan di suatu Negara. Upaya ini juga perlu diharmonisasikan juga dengan kebijakan yang ada ditingkat internasional guna Menjawab tantangan globalisasi.

Sebagai salah satu negara yang ikut menandatangani Deklarasi Millennium Development Goals (MDGs), Indonesia mempunyai komitmen untuk melaksanakan program program MDGs serta menjadikan program program MDGs sebagai bagian yang tak terpisahkan dari program pembangunan nasional baik jangka pendek, menengah, dan panjang, termasuk dalam hal ini adalah program pengentasan kemiskinan.

Pengentasan kemiskinan menjadi salah satu agenda/prioritas pemerintah Indonesia. Pemerintah Indonesia bersama semua perangkat negara dan seluruh unsur masyarakat memikul tanggung jawab untuk memberantas kemiskinan guna memenuhi komitmen pencapaian target MDGs pada 2015 mendatang. Bahkan, penanggulangan kemiskinan dalam pembangunan jangka menengah (RPJM) ditargetkan lebih cepat daripada target MDGs sendiri. MDGs telah menjadi salah satu bahan masukan penting dalam penyusunan kebijakan untuk mengentaskan kemiskinan di Indonesia Menurut Trilaksono (2015) prosentase penduduk miskin Jawa Timur Kota dan Desa dari Bulan September 2014 ke Bulan Maret 2015 mengalami kenaikan dari 12,28\% menjadi $12,34 \%$ yang artinya ada kenaikan sebesar 0,06 poin persen. Penduduk miskin di perkotaan pada Maret 2015 sebesar 31,84 persen dari total penduduk miskin Provinsi Jawa Timur atau sebesar 1.524,62 ribu jiwa.

Selama satu semester (September 2014 s.d. Maret 2015), kenaikan persentase penduduk miskin terjadi di perdesaan $(0,26$ poin persen $)$, sedang di perkotaan mengalami penurunan $(-0,11$ poin persen). Penanggulangan kemiskinan dan kelaparan merupakan salah satu isu global di mana melalui MGDs yang telah disepakati untuk menurunkan angka kemiskinan dan kelaparan di Indonesia hingga setengahnya pada tahun 2015. Secara internasional telah disusun 8 indikator untuk memantau pencapaian tujuan pertama ini (BPS, 2011), berikut:

a. Proporsi penduduk dengan pendapatan di bawah US\$ 1 per hari atau proporsi penduduk yang berada di bawah garis kemiskinan (poverty headcount ratio) 
b. Indeks Kedalaman Kemiskinan (poverty gap ratio)

c. Proporsi pendapatan atau konsumsi penduduk termiskin (share of the poorest quantile in national income or consumption)

d. Laju Pertumbuhan PDB per tenaga kerja

e. Rasio kesempatan kerja terhadap penduduk usia 15 tahun ke atas

f. Proporsi penduduk yang bekerja dengan status pekerja bebas dan pekerja keluarga terhadap total penduduk yang bekerja

g. Prevalensi balita kekurangan gizi (prevalence of underweight children under 5 years of age)

h. Proporsi penduduk dengan konsumsi gizi di bawah standar kecukupan gizi (proportion of population below minimum level of dietary energy consumption)

Dengan berpijak pada progress pencapaian MDGs Provinsi Jawa Timur, maka akan dapat menjadi evaluasi bagi Bappeda Provinsi dan Satuan Kerja Pemerintah Daerah untuk lebih focus memperbaiki bidang yang lambat progress pencapaian MDGsnya. Dengan dipetakannya Kabupaten/ Kota yang mengalami tingkat keparahan kemiskinan berdasar indikator MDGs yang memiliki scorecard merah, maka Kabupaten/ kota akan dapat lebih tepat dalam mengetahui permasalahan kemiskinan yang terjadi di wilayahnya sehingga nantinya akan dapat disusun program perencanaan pembangunan yang lebih berkualitas dengan tepat program, tepat kegiatan, tepat lokasi, tepat anggaran dan tepat penerima.

\section{METODE PENELITIAN}

Jenis penelitian yang digunakan dalam penelitian ini adalah jenis penelitian deskriptif. Populasi penelitian ini adalah data indikator MDGs delapan goals untuk Provinsi Jawa Timur dan kabupaten/kotanya. Sampel dalam penelitian ini adalah data indikator delapan goals MDGs tahun 2014.

Selain itu dalam penelitian ini akan diambil key informant untuk memberikan informasi kepada peneliti. Dalam menganalisis progress pencapaian teknik analisis Poverty dan Hunger Index, dimana indeks PHI-P mempunyai rentang nilai dari $\infty$ hingga 1. Jika nilai komponen PHIP lebih dari 1, dikoreksi menjadi 1, sehingga nilai maksimal adalah 1 .

Nilai negative berarti semakin jauh dari target MDGs dan bahkan lebih rendah dari kondisi nasional pada tahun 1990 (progres mundur). Nilai 1 artinya target MDGs pada tahun 2015 telah tercapai. Nilai PHI-P $\geq 0,5$ dapat diartikan sebagai progres cepat sedangkan nilai $0 \leq \mathrm{PHI}-\mathrm{P}<0,5$ berarti progres lambat. Rumus PHI-P yakni: PHI $-\mathbf{P}=\mathbf{1} / \mathbf{n} \sum(\mathbf{x i}-\mathbf{1 9 9 0}) /$ (2015 - 1990)

Teknik Scorecard MDGs digunakan untuk mendeteksi capaian indikator yang merah guna nantinya akan diinteraksikan untuk di petakan melalui Chart Priority. Dari hasil Chart Priority inilah nanti akan bisa di analisis dua kabupaten di Provinsi Jawa Timur yang mengalami tingkat keparahan kemiskinan untuk masingmasing Goal MDGs. Kemudian akan di dapat satu Kabupaten/kota paling banyak muncul di setiap Goal-nya.

\section{HASIL PEMBAHASAN}

Progress pencapaian Milienium Development Goals (MDGs) Provinsi Jawa Timur Tahun 2014 Progress pencapaian MDGs Provinsi Jawa Timur Tahun 2014 untuk 7 (tujuh) Goals yang ada dengan menggunakan teknik Poverty dan Hunger Index, didapat hasil sebagai berikut: 
Tabel Progress Capaian MDGs Provinsi Jawa Timur 2014

\begin{tabular}{|c|c|c|c|c|c|c|}
\hline TARGET & KODE & NAMA INDIKATOR & MIN & MAX & PHI-P & PROGRESS \\
\hline \multirow[t]{3}{*}{$\mathrm{IA}$} & 1.1 & Proporsi penduduk dengan pendapatan kurang dari 1 USD (PPP) per kapita per hari & 20.6 & 10.3 & 0.847 & CEPAT \\
\hline & 1.2 & Indeks Kedalaman Kemiskinan & 2.7 & 1.35 & & \\
\hline & 1.3 & Kontribusi Konsumsi penduduk pada Kuantil Terendah & 8.31 & 16.62 & & \\
\hline \multirow[t]{3}{*}{ IB } & 1.4 & Laju pertumbuhan PDB per tenaga kerja & 3.52 & 7.04 & 0.595 & CEPAT \\
\hline & 1.5 & 1.5. Rasio kesempatan kerja terhadap penduduk usia 15 tahun ke atas & 65 & 130.00 & & \\
\hline & 1.7 & Proporsi tenaga kerja yang berusaha sendiri dan pekerja bebas keluarga terhadap total kesempatan kerja & 71 & 35.50 & & \\
\hline \multirow[t]{3}{*}{ IC } & 1.8 & Prevalensi balita dengan berat badan rendah/kekurangan gizi & 31.08 & 15.54 & 0.497 & LAMBAT \\
\hline & 1.9 & Proporsi penduduk dengan asupan kalori di bawah tingkat konsumsi minimum $2000 \mathrm{KKAL} / \mathrm{kapita} / \mathrm{hari}$ & 17 & 8.50 & & \\
\hline & 1.9 & Proporsi penduduk dengan asupan kalori di bawah tingkat konsumsi minimum $1400 \mathrm{KKAL} /$ kapita/hari & 64.21 & 35.32 & & \\
\hline \multirow[t]{3}{*}{$\| \mathrm{A}$} & 2.1 & Angka Partisipasi Murni Sekolah Dasar & 88.7 & 100 & 0.807 & CEPAT \\
\hline & 2.2 & Proporsi murid kelas 1 yang berhasil me-namatkan Sekolah Dasar & 62 & 100.00 & & \\
\hline & 2.3 & Angka melek huruf penduduk usia 15-24 tahun, Perem-puan dan laki-laki & 96.6 & 100.00 & & \\
\hline \multirow[t]{7}{*}{ IIIA } & 3.1 & Rasio APM perempuan/laki-laki di SD & 100.27 & 100.00 & 1.864 & CEPAT \\
\hline & & Rasio APM perempuan/laki-laki di SMP & 99.86 & 100.00 & & \\
\hline & & Rasio APM perempuan/laki-laki di SMA & 93.67 & 100 & & \\
\hline & & Rasio APM perempuan/laki-laki di Perguruan Tinggi & 74.06 & 100 & & \\
\hline & 3.1.a & Rasio melek huruf Perempuan terhadap laki-laki pada kelompok usia 15-24 tahun & 98.44 & 100.00 & & \\
\hline & 3.2 & Kontribusi perempuan dalam pekerja upahan di sektor non pertanian (KPPNP). & 29.24 & 58.48 & & \\
\hline & 3.3. & Proporsi kursi yang diduduki perempuan di DPR & 12.5 & 25 & & \\
\hline \multirow[t]{3}{*}{ IVA } & 4.1 & Angka Kematian Balita per 1000 kelahiran hidup & 97 & 32 & 1.111 & CEPAT \\
\hline & 4.2 & Angka Kematian Bayi (AKB) per 1000 kelahiran hidup & 68 & 23 & & \\
\hline & 4.3 & Persentase anak usia 1 tahun yang diimunisasi campak & 44.5 & 89 & & \\
\hline \multirow[t]{3}{*}{ VA } & 5.2 & Proporsi kelahiran yang ditolong tenaga kesehatan terlatih & 40.7 & 81.4 & 0.666 & CEPAT \\
\hline & 5.3 & Angka pemakaian kontrasepsi/CPR bagi perempuan menikah usia 15-49, Semua Cara & 49.7 & 99.4 & & \\
\hline & $5.3 a$ & Angka pemakaian kontrasepsi/CPR bagi perempuan menikah usia 15-49, Cara Moderen & 47.1 & 94.2 & & \\
\hline \multirow[t]{4}{*}{ VB } & 5.4 & Angka kelahiran remaja (perempuan usia 15-19 tahun) per 1.000 perempuan usia $15-19$ tahun & 67 & 33.5 & 0.597 & CEPAT \\
\hline & $5.5 a$ & Cakupan pelayanan Antenatal sedikitnya empat kali kunjungan & 75 & 150 & & \\
\hline & $5.5 b$ & Cakupan pelayanan Antenatal sedikitnya satu kali kunjungan & 56 & 112 & & \\
\hline & 5.6 & Unmet Need (kebu-tuhan keluarga be-rencana/KB yang tidak terpenuhi) & 12.7 & 6.35 & & \\
\hline \multirow[t]{3}{*}{ VIC } & 6.6 & Angka kejadian ma-laria (per 1000 pen-duduk) & 4.68 & 2.34 & 1.602 & CEPAT \\
\hline & $6.10 \mathrm{a}$ & Proporsi kasus tu-berkulosis yang terdeteksi & 20 & 70 & & \\
\hline & $6.10 \mathrm{~b}$ & Yang diobati de-ngan DOTS (Di-rectly Observed Treatment Short Course) & 87 & 85 & & \\
\hline \multirow[t]{3}{*}{ VII } & 7.8 & Proporsi rumah tang-ga dengan akses ber-kelanjutan terhadap air minum layak, perkotaan dan perdesaan & 27.73 & 68.87 & 1.123 & CEPAT \\
\hline & 7.9 & Proporsi rumah tang-ga dengan akses ber-kelanjutan terhadap sanitasi layak, perko-taan dan perdesaan & 24.81 & 62.41 & & \\
\hline & 7.10 & Proporsi rumah tangga kumuh perkotaan & 20.75 & 6 & & \\
\hline
\end{tabular}

\section{KETERANGAN}

IA Menurunkan Hingga Setengahnya Proporsi Penduduk dengan Tingkat Pendapatan Kurang dari USD1,00 (PPP) per Hari dalam Kurun Waktu 1990-2015

IB Mewujudkan Kesempatan Kerja Penuh dan Produktif serta Pekerjaan yang Layak untuk Semua, Termasuk Perempuan dan Kaum Muda

IC Menurunkan Hingga Setengahnya Proporsi Penduduk yang Menderita Kelaparan dalam Kurun Waktu 1990-2015

IIA Menjamin pada 2015 Semua Anak-Anak, Laki-Laki Maupun Perempuan di Manapun Dapat Menyelesaikan Pendidikan Dasar

IIIA Menghilangkan Ketimpangan Gender di Tingkat Pendidikan Dasar dan Lanjutan pada Tahun 2005, dan di Semua Jenjang Pendidikan Tidak Lebih dari Tahun 2015

IVA Menurunkan Angka Kematian Balita (AKBA) Hingga Dua Per Tiga dalam Kurun Waktu 1990-2015

VA Menurunkan Angka Kematian Ibu Hingga Tiga per Empat dalam Kurun Waktu 1990-2015

VB Mewujudkan Akses Kesehatan Reproduksi Bagi Semua pada Tahun 2015

VIC Mengendalikan Penyebaran dan Mulai Menurunkan Jumlah Kasus Baru Malaria dan Penyakit Utama Lainnya Hingga Tahun 2015

VII Menjamin Keberlangsungan Lingkungan

Berdasar Tabel di atas terlihat

bahwa hampir seluruh target dari 7 (tujuh) Goal yang ada pencapaian MDGs di Jawa Timur progress-nya cepat terkecuali Target IC. Bahkan

untuk Goal 3, 4, 5 dan 6 nilai PHI-P nya $>1$ artinya nilai maksimal dalam arti untuk goals tersebut Provinsi Jawa Timur telah mencapai targetnya.

Program Studi Manajemen Universitas Muhammadiyah Gresik Indonesia 
Target IC menurunkan proporsi penduduk yang menderita kelaparan menjadi setengahnya antara tahun 1990-2015 indikator Prevalensi balita kurang gizi (BKG), dan Proporsi penduduk yang berada di bawah garis konsumsi minimum 1400 kkal per kapita per hari serta 2000 kkal per kapita per hari untuk Jawa Timur progress pencapaiannya lambat. Berdasar tabel di bawah terlihat dua dari tiga indikator target IC nilainya masih belum mencapai target MDGs.

Tabel Status Capaian Target IC

\begin{tabular}{|l|c|c|c|c|c|l|}
\hline \multicolumn{7}{|c|}{$\begin{array}{c}\text { TARGET : Menurunkan proporsi penduduk yang menderita kelaparan } \\
\text { menjadi setengahnya antara tahun 1990-2015 }\end{array}$} \\
\hline \multicolumn{1}{|c|}{ INDIKATOR } & $\begin{array}{c}\text { ACUAN } \\
\text { DASAR } \\
\text { NASIONAL }\end{array}$ & PENCAPAIAN & $\begin{array}{c}\text { TARGET } \\
\text { MDGs } \\
\mathbf{2 0 1 5}\end{array}$ & STATUS & SUMBER \\
\hline & & $\mathbf{2 0 1 3}$ & $\mathbf{2 0 1 4}$ & & & \\
\hline $\begin{array}{l}\text { 1.8. Prevalensi balita } \\
\text { dengan berat badan } \\
\text { rendah/kekurangan gizi }\end{array}$ & $\begin{array}{c}31,08 \% \\
(1989)\end{array}$ & 12.1 & 12.3 & 15.5 & $\square$ & DINKES \\
\hline $\begin{array}{l}\text { 1.9. Proporsi penduduk } \\
\text { dengan asupan kalori di } \\
\text { bawah tingkat konsumsi } \\
\text { minimum 1400 } \\
\text { kkal/kapita/ hari }\end{array}$ & $\begin{array}{c}17,00 \% \\
(1990)\end{array}$ & 18.37 & 13.94 & 8,5 & () & BPS \\
\hline $\begin{array}{l}\text { 1.9. Proporsi penduduk } \\
\text { dengan asupan kalori di } \\
\text { bawah tingkat } \\
\text { konsumsi minimum } \\
\text { 2000 kkal/kapita/ hari }\end{array}$ & $\begin{array}{c}64,21 \% \\
(1990)\end{array}$ & 71.77 & 66.47 & 35.32 & $\square$ & BPS \\
\hline
\end{tabular}

Untuk proporsi penduduk dengan asupan kalori di bawah tingkat konsumsi minimum $1400 \mathrm{kkal} /$ kapita/ hari statusnya masih akan tercapai, sedangkan yang proporsi penduduk dengan asupan kalori dibawah tingkat konsumsi minimum $2000 \mathrm{kkal} / \mathrm{kapita} /$ hari statusnya perlu perhatian khusus.

Prevalensi kekurangan gizi pada balita untuk Provinsi Jawa Timur mencapai 12,3 persen pada tahun 2014 berada dibawah target MDGs 2015 sebesar 15,50 persen. Namun demikian capaian ini masih terus ditingkatkan karena dibeberapa wilayah masih belum mencapai target yang ditentukan seperti Kabupaten Lumajang, Jember, Bondowoso, Situbondo, Tuban, Pamekasan, Sumenep, Kota Probolinggo, Pasuruan dan Surabaya. Rata-rata yang Prevalensi Balita Kurang
Gizinya belum mencapai target yang ditetapkan adalah kabupaten yang ada di Pantai Utara Pulau Jawa (Pantura) dan umumnya wilayah pesisir.

Kabupaten/Kota di Provinsi Jawa Timur dengan tingkat keparahan kemiskinan di tinjau berdasar indikator MDGs tahun 2014

Langkah pertama yang dilakukan untuk melihat tingkat keparahan kemiskinan wilayah kabupaten/kota di Provinsi jawa Timur berdasar indikator MDGs adalah dengan melakukan penilaian scorecard untuk seluruh kabupaten/kota di tiap indikator MDGs. Sebanyak 28 indikator yang datanya tersedia di Provinsi Jawa Timur untuk tiap Kabupaten Kota, dengan hasil scorecard sebagai berikut: 
Tabel Hasil Scorecard

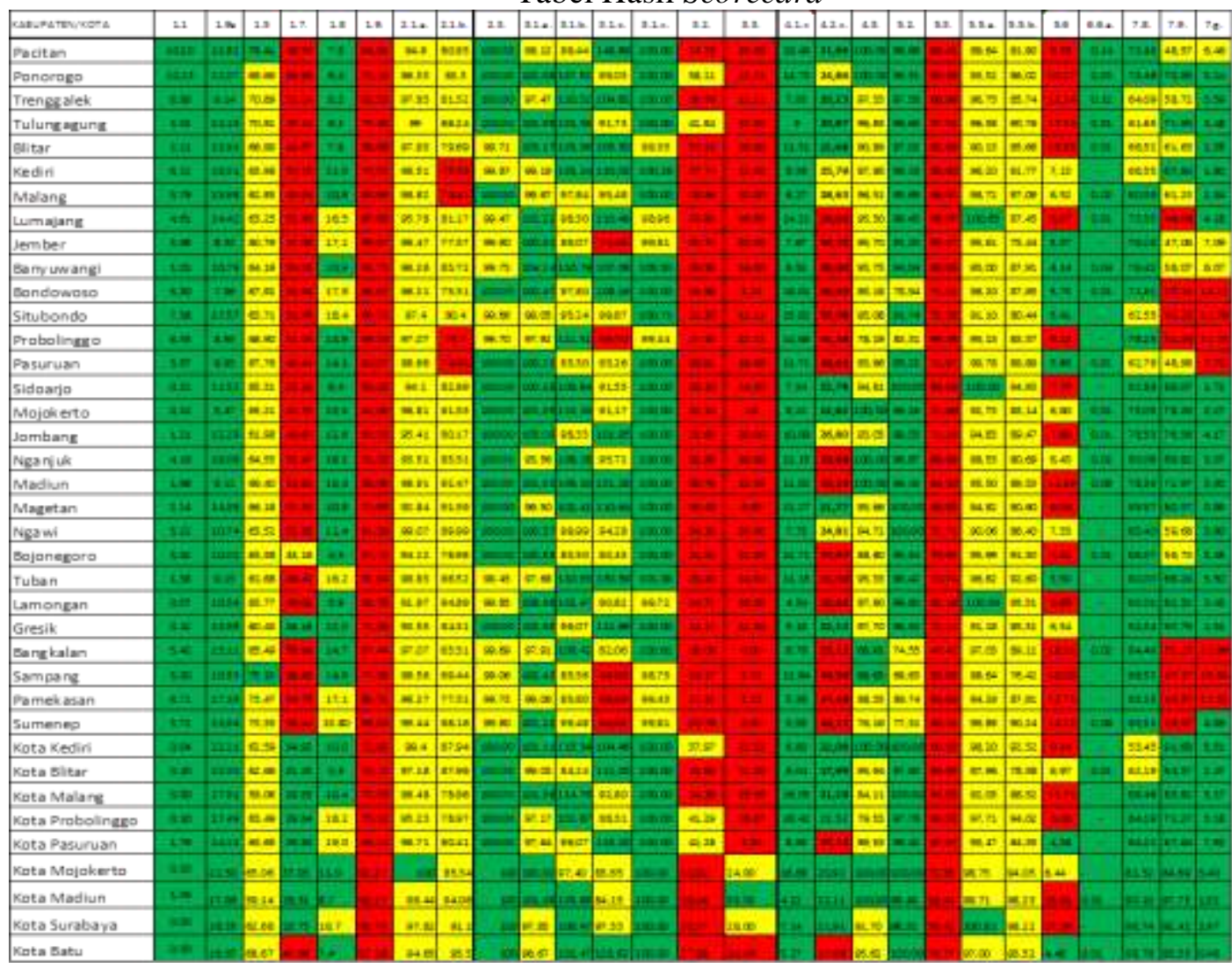

Berdasar tabel di atas nampak bahwa indikator yang rata-rata capaianya masih merah untuk kabupaten/kota di Provinsi Jawa Timur adalah indikator 1.7 (Proporsi penduduk yang bekerja dengan status pekerja bebas dan pekerja keluarga terhadap total penduduk bekerja), 1.9 (Proporsi penduduk dengan asupan kalori di bawah tingkat konsumsi minimum (2.000 kkal kapita per hari), 3.1c (Rasio jenis kelamin Angka Partisipasi Murni (RAPM) anak perempuan terhadap anak laki-laki di jenjang pendidikan di $\left.\mathrm{SM}^{*}\right), 3.2$ (Kontribusi perempuan dalam pekerja upahan di sektor non pertanian*), 3.3 (Proporsi anggota parlemen perempuan*), 4.2x (Kasus Kematian Bayi*), 5.3 (Angka pemakaian kontrasepsi (CPR) bagi PUS (Pasangan Usia Subur) usia 15-49 tahun semua cara*), 5.6 (Kebutuhan ber-KB yang tidak terpenuhi (unmet need $^{*}$ ), 7.9 (Proporsi rumah tangga dengan akses berkelanjutan terhadap sanitasi dasar), 7.g (Proporsi rumah tangga di kawasan kumuh). Dari 7 Goal MDGs, yang rata rata kabupaten/kota di provinsi Jawa Timur capaian scorecardnya merah adalah Goal I, Goal III, Goal IV, Goal V dan Goal VII. Untuk Goal II hanya ada beberapa kabupaten/ kota saja.

Berikutnya menginteraksikan 2 indikator masing-masing Goal (Goal I, III, IV, V, VII) yang capaiannya rata-rata untuk Kabupaten/ Kota di Provinsi Jawa Timur merah. Selanjutnya dilakukan olah data dengan menggunakan alat Chart Priority. Dari hasil penggunaan alat Chart Priority akan terpilih 2 Kabupaten/Kota yang memiliki kondisi paling buruk dari dua indikator yang diinteraksikan. Dua Kabupaten/Kota itulah yang terpilih sebagai kabupaten/kota yang memiliki tingkat keparahan kemiskinan paling tinggi untuk masing-masing Goal. 


\section{Goal I :Menanggulangi Kemiskinan dan Kelaparan}

Berdasar Tabel Hasil Scorecard tersebut di atas terlihat bahwa untuk Goal I, indikator yang rata-rata capaiannya untuk Kabupaten/ Kota di Provinsi Jawa Timur merah adalah indikator 1.7 (Proporsi penduduk yang bekerja dengan status pekerja bebas dan pekerja keluarga terhadap total penduduk yang bekerja) dan 1.9 (Proporsi penduduk dengan asupan kalori di bawah tingkat konsumsi minimum (2.000 kkal kapita per hari). Adapun hasil interaksi kedua indikator tersebut sebagai berikut :

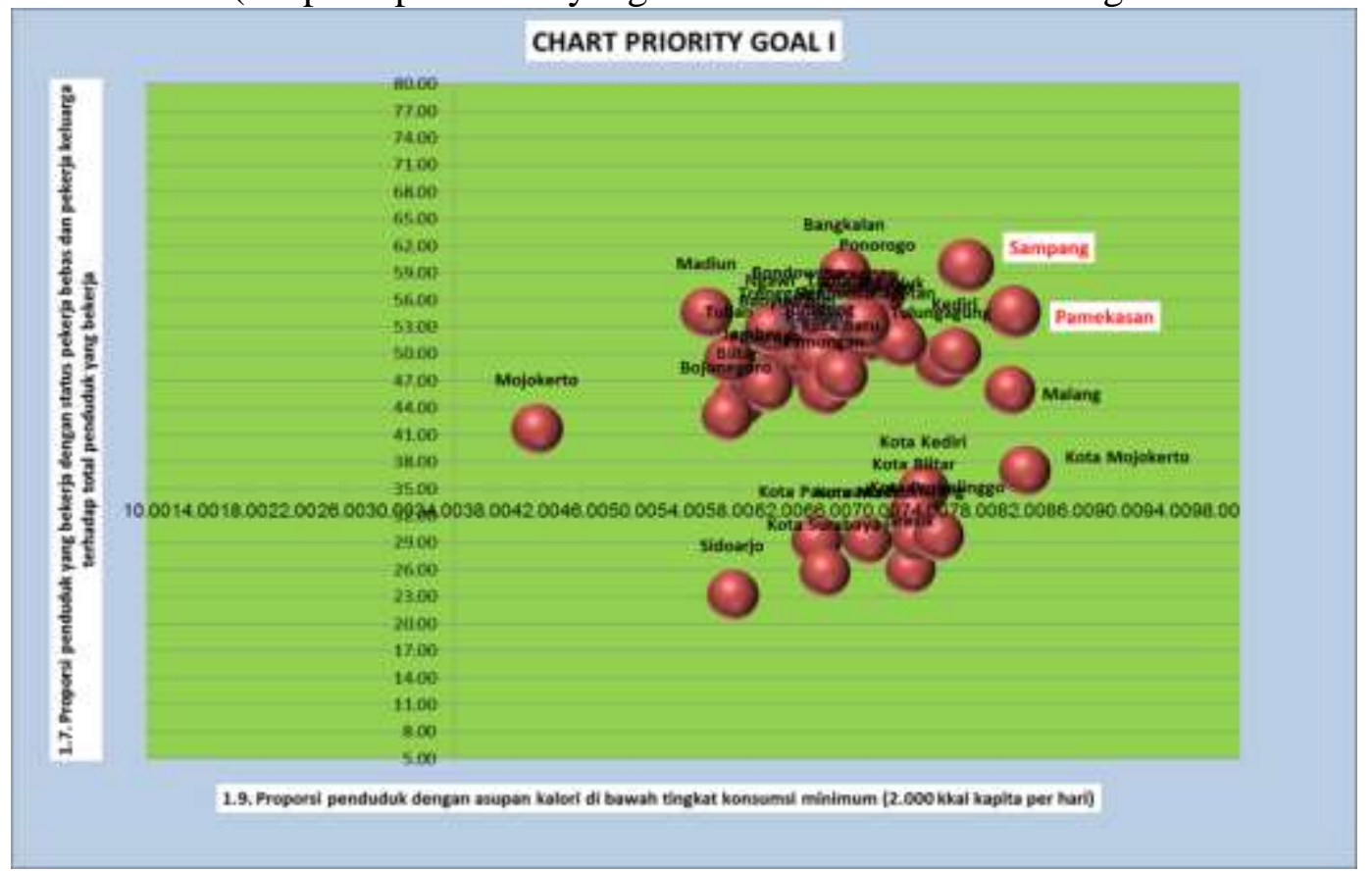

Gambar Chart Priority Goal 1

Berdasar Gambar di atas terlihat bahwa Kabupaten Sampang dan Pamekasan merupakan kabupaten yang memiliki tingkat keparahan paling tinggi untuk Goal I, karena disamping tingkat Proporsi Penduduk dengan asupan kalori minimum (2000 $\mathrm{kkal} / \mathrm{kapita} / \mathrm{hari}$ )-nya sangat tinggi, Proporsi penduduk yang bekerja dengan status pekerja bebas dan pekerja keluarga terhadap total penduduk yang bekerja sangat tinggi juga. Artinya di kedua Kabupaten tersebut selain masih banyak sekali penduduk yang tingkat konsumsinya masih berada di bawah tingkat konsumsi yang dianjurkan (2000 $\mathrm{kkal} / \mathrm{kapita} / \mathrm{hari}$ ), juga masih banyak juga penduduk di kedua kabupaten tersebut yang bekerja pada kegiatan informal.
Seperti dikaetahui bahwa metode yang digunakan oleh Badan Pusat Statistik (BPS) sebagai indikator kemiskinan adalah dengan mengukur jumlah kalori yang dikonsumsi per orang per hari. Standar kebutuhan minimum per orang per hari menurut BPS adalah 2100 kalori. Pemenuhan jumlah kalori tersebut sudah diperhitungkan dari 52 jenis komoditi yang dianggap mewakili pola konsumsi penduduk.

\section{Goal III : Mendorong Kesetaraan Gender dan Pemberdayaan Perempuan}

Berdasar Tabel Hasil Scorecard terlihat bahwa untuk Goal III, indikator yang rata-rata capaiannya untuk Kabupaten/Kota di Provinsi Jawa Timur merah adalah indikator 
3.2 (Kontribusi perempuan dalam pekerja upahan di sektor non pertanian*) dan 3.3 (Kontribusi perempuan dalam pekerja upahan di sektor non pertanian*). Dan hasil interaksi kedua indikator tersebut dengan menggunakan chart priority adalah sebagai berikut:

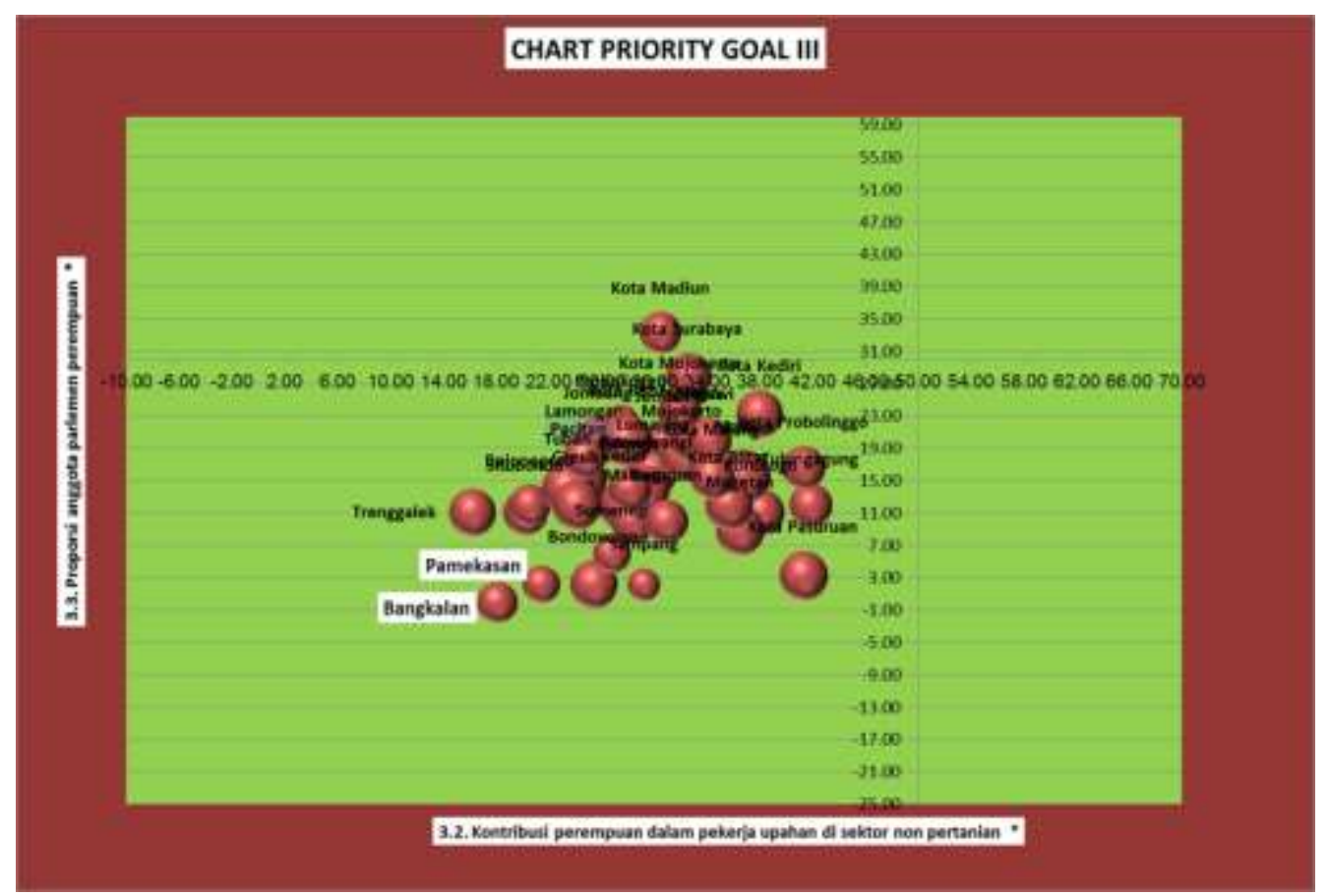

Gambar Chart Priority Goal III

Berdasar gambar chart priority tersebut di atas terlihat bahwa Kabupaten Pamekasan dan Bangkalan merupakan dua kabupaten di provinsi Jawa Timur tingkat partisipasinya di seknor non pertanian maupun di parlemen paling rendah. Sektor non pertanian adalah semua sektor kegiatan ekonomi di luar pertanian sesuai dengan Klasifikasi Baku Lapangan Usaha Indonesia (KBLI).

Sektor non pertanian yaitu pertambangan dan penggalian, industri pengo-lahan, listrik dan gas, konstruksi/bangunan, perdagangan, hotel dan rumah makan, transportasi dan pergudangan, informasi dan komu-nikasi, keuangan dan asuransi, jasa pendidik-an, jasa kesehatan, jasa kemasyarakatan, pemerintahan dan perorangan, dan lainnya (real estate, penyedia air, dan lain-lain). Jika tingkat partisipasi perempuan di sector non pertanian sangat rendah maka artinya di kedua kabupaten tersebut tingkat keterbukaan pasar kerja bagi perempuan di sektor non pertanian relative masih sangat kecil. Masyarakt perempuan masih lebih banyak dituntut untuk bekerja di sector pertanian atau hanya sebagai ibu rumah tangga.

Ketidakterbukaan partisipasi perempuan di sector publik tersebut mengindikasikan bahwa kesempatan kerja dan berusaha serta pastisipasi perempuan di kedua kabupaten tersebut masih sangat lemah. Padahal dalam Indikator kemiskinan berdasar pengukuran pemenuhan kebutuhan sesuai hak-hak dasar yang diikemukakan oleh Bappenas disebutkan bahwa diantara indikator kemiskinan adalah terbatasnya kesempatan kerja dan berusaha serta lemahnya partisipasi. 


\section{Goal IV: Menurunkan Angka Kematian Anak}

Berdasar indikator kemiskinan yang ditetapkan oleh Bappenas, disebutkan salah satunya adalah terbatasnya akses dan rendahnya mutu layanan kesehatan yang disebabkan oleh kesulitan mendapat layanan kesehatan dasar, rendahnya mutu layanan kesehatan dasar, kurangnya pemahaman terhadap perilaku hidup sehat dan kurangnya layanan kesehatan reproduksi; jarak fasilitas layanan kesehatan yang jauh serta biaya perawatan dan pengobaian yang mahal. Dilihat dari hasil scorecard dalam Tabel 3 tampak bahwa ada dua indikator kesehatan yang rata-rata capaian kabupaten kota di Provinsi Jawa Timur masih merah yakni indikator 4.2x ( angka kematian bayi) dan 4.3 (proporsi anak usia 1 tahun diimunisasi campak). Dari 38 Kabupaten kota yang ada di Provinsi Jawa Timur, Kabupaten Probolinggo dan Bangkalan merupakan dua kabupaten yang memiliki tingkat keparahan kondisi kesehatan paling tinggi, dimana selain angka kematian bayi yang sangat tinggi juga proporsi anak usia 1 tahun yang diimunisasi campak sangat minim.

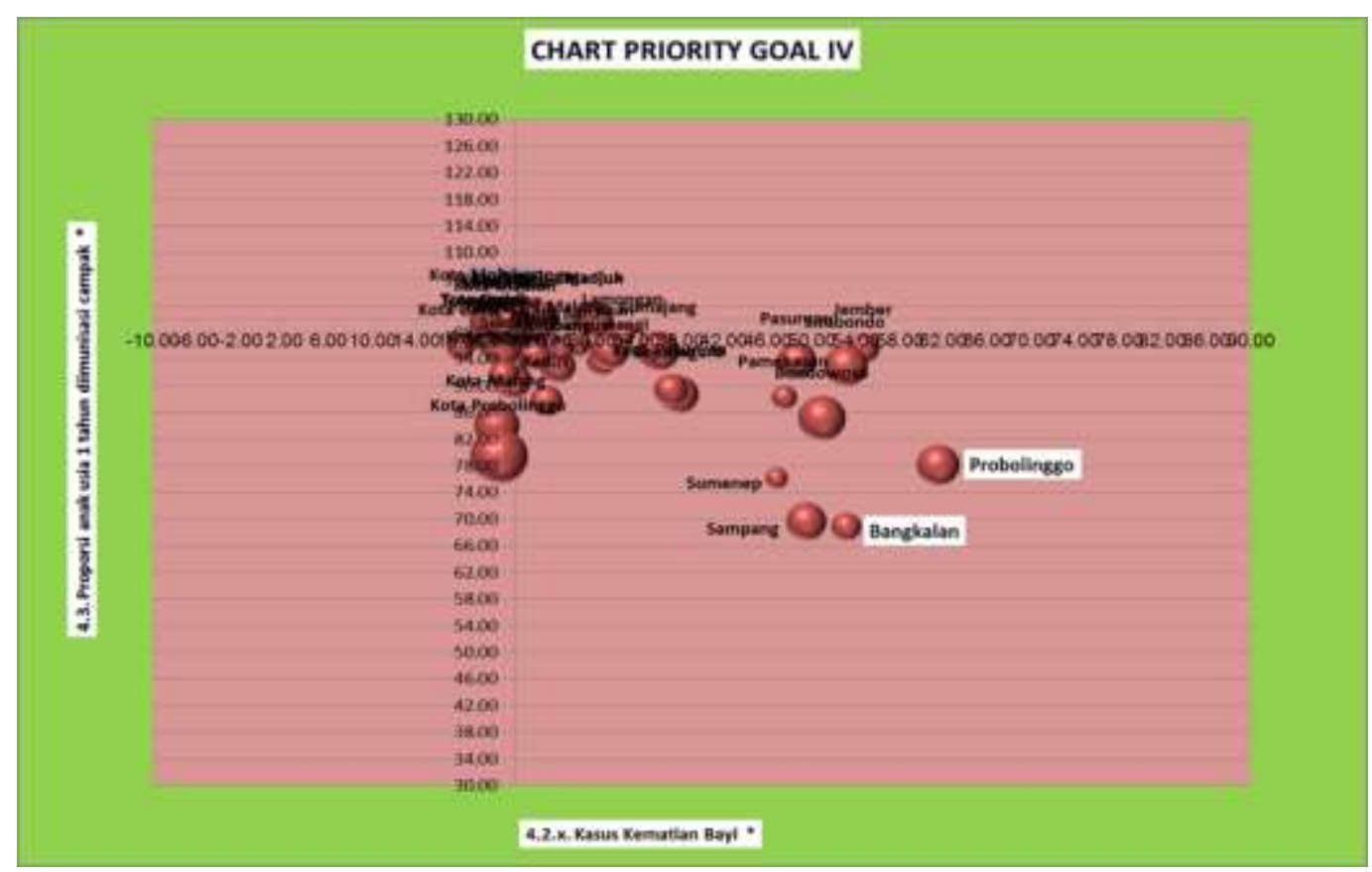

Gambar Chart Priority Goal IV

Goal V : Meningkatkan Kesehatan

Ibu

Kurangnya layanan kesehatan reproduksi yang menjadi salah satu indikator kemiskinan suatu wilayah menjadikan Pemerintah menetapkan terwujudnya Akses Kesehatan Reproduksi bagi Semua menjadi salah satu Goal dalam Millenium Development Goals (MDGs). Namun disayangkan untuk dua indikator dari Goal V yakni 5.3 (Angka pemakaian kontrasepsi (CPR) bagi PUS
(Pasangan Usia Subur) usia 15-49 tahun semua cara*) dan 5.6 (Kebutuhan ber-KB yang tidak terpenuhi (unmet need)*) rata-rata kabupaten kota di provinsi Jawa Timur capaiannya masih merah.

Berdasar hasil interaksi kedua indikator tersebut ke dalam alat chart priority didapatkan hasil bahwa Kabupaten Bangkalan dan Kabupaten Sumenep merupakan kabupaten yang memiliki keparahan layanan kesehatan reproduksi paling tinggi. 


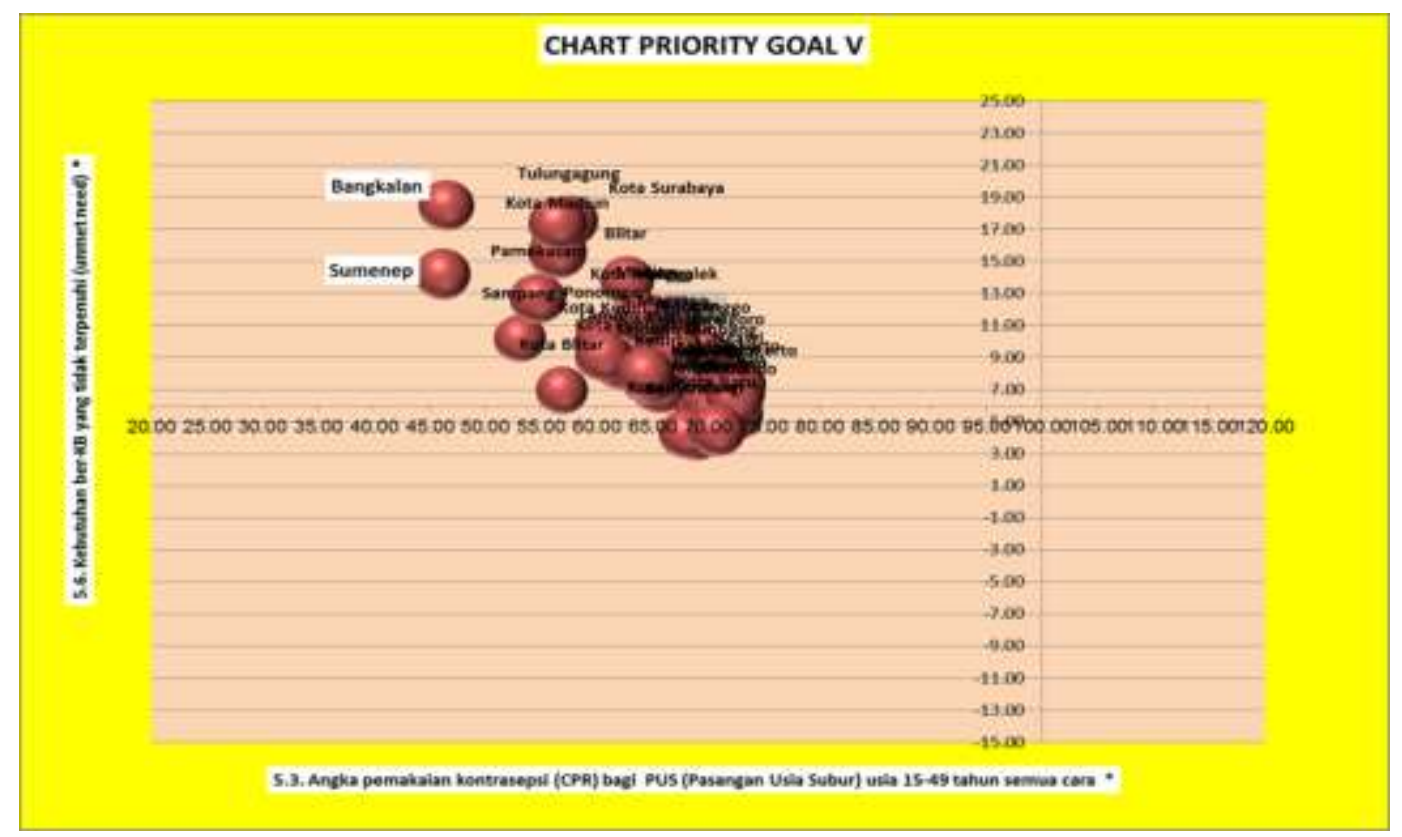

Gambar Chart Priority Goal V

Di mana terlihat pada gambar di atas bahwa angka pemakaian kontrasepsi bagi PUS dengan semua cara di kedua kabupaten tersebut masih lebih rendah disbanding 36 kabupaten lainnya. Selain itu tingkat unmeet need-nya juga cukup tinggi khususnya untuk Kabupaten Bangkalan.

\section{Goal VII : Menjamin Kelestarian Lingkungan Hidup}

Menurunkan Hingga Setengahnya Proporsi Rumah Tangga Tanpa Akses Berkelanjutan Terhadap Air Minum Layak dan Sanitasi Dasar serta peningkatan yang signifikan dalam kehidupan penduduk miskin di permukiman kumuh (Minimal 100 Juta) merupakan bagian dari target MDGs yang ingin di capai oleh pemerintah Indonesia dalam rangka meminimalisasi atau menurunkan angka kemiskinan yang ada, karena seperti diketahui bahwa terbatasnya akses layanan perumahan dan sanitasi merupakan salah satu dari indikator kemiskinan yang ditetapkan oleh Bappenas.

Berdasar Tabel diatas terlihat bahwa untuk Goal VII, indikator 7.9 (Proporsi rumah tangga dengan akses berkelanjutan terhadap sanitasi dasar ) dan 7.g (Proporsi rumah tangga di kawasan kumuh ) capaiannya merah untuk rata-rata kabupaten kota di Provinsi Jawa Timur. Dan dari 38 kabupaten/kota yang ada, Kabupaten Bondowoso dan Sampang memiliki akses layanan perumahan dan sanitasi paling buruk. Kabupaten Sampang proporsi rumah tangga kumuhnya paling besar sedangkan Kabupaten Bondowoso layanan sanitasi dasarnya paling parah. Jadi kedua kabupatn tersebut selain memiliki akses layanan perumahan yang sangat buruk, juga akses sanitasi dasarnya jelek. 


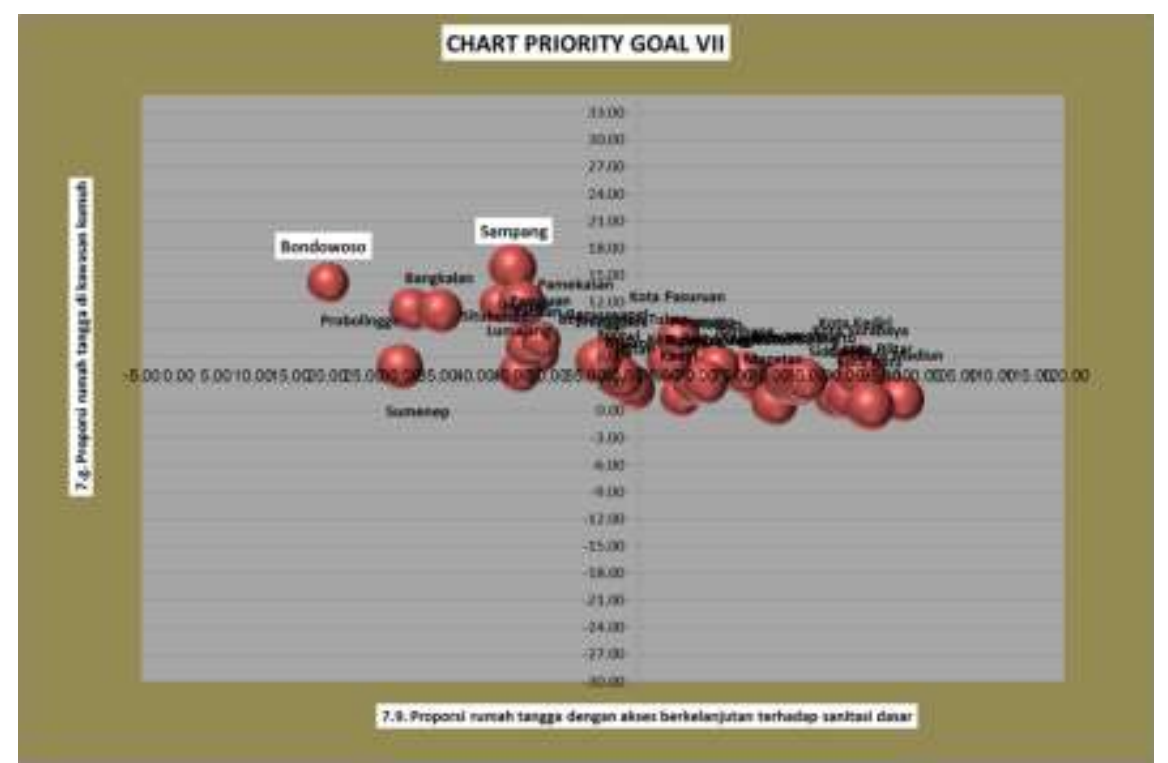

Gambar Chart Priority Goal VII

Berdasarkan kondisi keparahan kemiskinan melalui indikator MDGs tersebut, dari 5 Goal yang ada maka

Tabel Nama Kabupaten Yang Mengalami Tingkat Keparahan Kemiskinan

\begin{tabular}{|l|c|c|c|c|c|}
\hline Kab/Kota & GOAL I & GOAL II & GOAL IV & GOAL V & GOAL VII \\
\hline Pamekasan & $\sqrt{ }$ & $\sqrt{ }$ & & & \\
\hline Sampang & $\sqrt{ }$ & & & & $\sqrt{ }$ \\
\hline Bangkalan & & $\sqrt{ }$ & $\sqrt{ }$ & $\sqrt{ }$ & \\
\hline Probolinggo & & & $\sqrt{ }$ & $\sqrt{ }$ & \\
\hline Bondowoso & & & & & $\sqrt{ }$ \\
\hline Sumenep & & & & & \\
\hline
\end{tabular}

Pada Tabel tersebut di atas terlihat bahwa Kabupaten Bangkalan adalah Kabupaten yang memiliki tingkat keparahan kemiskinan paling tinggi yakni Goal III, Goal IV dan Goal V. Artinya di Kabupaten Bangkalan, selain kesempatan kerja dan berusaha serta partisipasi perempuan dalam kegiatan public-nya terbatas, layanan kesehatan anak maupun layanan kesehatan reproduksinya-pun juga masih sangat rendah. Padahal layanan kesehatan anak dan kesehatan reproduksi yang tidak maksimal atau kurang diperhatikan akan mampu meningkatkan jumlah sumber daya manusia yang tidak berkualitas. Tingginya angka kematian bayi menunjukkan bahwa layanan secara garis besar dapat dilihat hasil berikut: kesehatan reproduksi di wilayah tersebut masih rendah.

Kesehatan dan kemisksinan merupakan dua hal yang tidak bisa dipisahkan. Bank Dunia pernah melakukan studi dengan membagi keadaan kesehatan antara kelompok penduduk berpenghasilan tinggi dan rendah. Hasilnya tingkat kematian anak pada penduduk miskin empat kali lebih besar disbanding penduduk berpenghasilan tinggi. Dan keluarga miskin akan selalu berusahan mengganti anaknya yang meninggal dengan cara memiliki jumlah anak yang lebih banyak. Jika keluarga tersebut memiliki jumlah anak yang banyak maka keluarga tersebut tidak akan mampu melakukan investasi yang cukup untuk pendidikan dan 
kesehatan untuk setiap anaknya. Pola ini menuntun pengertian bahwa tingkat kematian bayi yang tinggi berimplikasi pada meningkatnya pertumbuhan penduduk secara cepat dengan segala konsekwensinya. (Atmawikarta, 2009)

$$
\text { Jadi rendahnya layanan }
$$

kesehatan anak dan kesehatan reproduksi yang bisa menyebabkan angka kematian bayi yang cukup tinggi otomatis juga menyumbang tingginya angka kemiskinan karena kematian bayi tinggi menyebabkan tingkat kelahiran semakin lebih besar, dan menjadikan jumlah anak semakin banyak akhirnya orang tua tidak mampu melakukan investasi yang cukup untuk pendidikan dan kesehatan setiap anaknya yang artinya kemiskinan akan semakin bertambah. Berdasar Tabel diatas juga terlihat bahwa kabupaten yang memiliki tingkat keparahan kemiskinan, ratarata adalah kabupaten yang berada di wilayah Pantai utara Pulau Jawa (Pantura) dan kabupaten yang terletah di wilayah Kepulauan Madura.

\section{SIMPULAN}

\section{REKOMENDASI}

\section{Simpulan}

1. Progress pencapaian MDGs di Provinsi Jawa Timur dari 7 (tujuh) Goal yang ada progress-nya "cepat" terkecuali Target IC pada Goal I. Untuk Target IC progress pencapaian di Provinsi Jawa Timur "lambat"

2. Kabupaten yang mengalami tingkat keparahan kemiskinan untuk Goal I adalah Kabupaten Sampang dan Kabupaten Pamekasan

3. Kabupaten yang mengalami tingkat keparahan kemiskinan untuk Goal III adalah Kabupaten Bangkalan dan Kabupaten Pamekasan
4. Kabupaten yang mengalami tingkat keparahan kemiskinan untuk Goal IV adalah Kabupaten Probolinggo dan Kabupaten Bangkalan

5. Kabupaten yang mengalami tingkat keparahan kemiskinan untuk Goal $\mathrm{V}$ adalah Kabupaten Bangkalan dan Kabupaten Sumenep

6. Kabupaten yang mengalami tingkat keparahan kemiskinan untuk Goal VII adalah Kabupaten Sampang dan Kabupaten bondowoso

7. Kabupaten yang memiliki tingkat keparahan kemiskinan paling tinggi untuk masing-masing Goal MDGs adalah Kabupaten Bangkalan yakni pada Goal III, IV dan V.

\section{Rekomendasi}

1. Untuk mempercepat progress pencapaian Target IC yakni menurunkan proporsi penduduk yang menderita kelaparan menjadi setengahnya antara tahun 19902015 di Provinsi Jawa Timur adalah dengan cara:

1) Meningkatkan akses perolehan makanan yang aman dan bergizi serta mendapatkan intervensi layanan lainnya suplementasi gizi bagi anak balita dan ibu hamil lewat posyandu di masingmasing desa, puskesmas ataupun unit-unit kesehatan lainnya.

2) Memperkuat pemberdayaan masyarakat dan merevitalisasi fungsi posyandu

3) Memperkuat lembaga ditingkat pusat dan daerah yang mempunyai kewenangan kuat dalam merumuskan kebijakan dan program dibidang pangan dan gizi

4) Meningkatkan ketahanan pangan di setiap daerah

2. Provinsi Jawa Timur lebih focus terhadap penyebab kondisi keparahan kemiskinan yang 
dialami oleh Kabupaten-Kabupaten yang terindikasi mengalami tingkat keparahan kemiskinan tertinggi di masing-masing Goalnya dengan cara melakukan kajian yang lebih mendalam terhadap indikatorindikatornya bisa dengan melakukan kajian mandiri atau bekerja sama dengan dunia pendidikan atau lembaga-lembaga penelitan lainnya, sehingga dapat ditemukan solusi yangdiharapkan nantinya tepat program, tepat kegiatan, tepat anggaran, tepat lokasi dan tepat penerima.

3. Pemerintah Kabupaten Bangkalan hendaknya lebih memperhatikan akan layanan kesehatan anak dan layanan kesehatan reproduksi dengan cara:

1) Merevitalisasidan meningkatkan fungsi posyandu yang ada

2) Meningkatkan pemahaman pada ibu tentang pentingnya ASI dan makanan bergizi untuk anak dan ibu hamil melalui sosialisasi atau penyuluhan-penyuluhan

3) Meningkatkan pemberian imunisasi lengkap terhadap balita khususnya
4. Pemerintah Kabupaten Bangkalan hendaknya mulai lebih banyak memberikan peluang atau kesempatan terhadap perempuan untuk bekerja di sector public dengan cara memberikan kelonggaran persyaratan (spesifikasi) kerja yang tidak memberatkan para perempuan terkait dengan kodratnya sebagai istri dan ibu rumah tangga.

\section{DAFTAR PUSTAKA}

Atmawikarta, 2009, Bappenas.go.id

Badan Perencanaan Pembangunan Nasional , 2005 oceannaz, 2010, in Komunitas, Masyarakat,oceannaz.wordpres s.com/author/oceannaz/page/4

Trilaksono, Bagyo, 2015, Capaian MDGs Jawa Timur 2014

www. bps.go.id 